\title{
Antioxidant and Anti-Inflammatory Activities of Extracts of Traditional Medicinal Plants Mixtures 1 and 2
}

Eun Kyung Cho and Young Ju Choi*

Department of Food and Nutrition, College of Medical Life Sciences, Silla University, Busan 617-736, Korea

Received March 15, 2011 /Accepted April 1, 2011

\begin{abstract}
This study was conducted to investigate traditional medicinal plants (TMP) 1 and 2, two different multi-herbal mixtures consisting of 24 herbs. Regarding the contents of flavonoid compounds, the ethanol extract (EE) of TMP2 yielded the highest content of flavonoid compounds (40.981 mg/g), followed by EE of TMP1 (28.23 mg/g), hot water extract of TMP2 (WE, $10.046 \mathrm{mg} / \mathrm{g}$ ), and WE of TMP1 $(6.59 \mathrm{mg} / \mathrm{g})$. Antioxidant activities of EE and WE of TMP1 and TMP2 were measured based on DPPH radical scavenging activity. At $1 \mathrm{mg} / \mathrm{ml}$, the highest DPPH radical scavenging activity was shown in EE of TMP2 (96\%), followed by EE of TMP1 (94\%). Nitric oxide (NO) production by RAW264.7 macrophage cells stimulated with lipopolysaccharide (LPS) was reduced to 82, 77, 86, and $47 \%$ by addition of $500 \mu \mathrm{g} / \mathrm{ml}$ of EE and WE of TMP1 and TMP2, respectively. These results were not due to the cytotoxicity of the extracts. NO synthesis was increased by 2.3, 3.6, 3.0, and 1.8 fold by addition of $500 \mu \mathrm{g} / \mathrm{ml}$ of EE and WE of TMP1 and TMP2, respectively. These results show that medicinal plants play a significant role in antioxidative activity and activation of the immune system in the pathogenesis of inflammatory diseases, and different mixtures of the medicinal plants showed different effects.
\end{abstract}

Key words : Medicinal plants, flavonoid, antioxidant activity, nitric oxide, anti-inflammatory activity

\section{서 론}

최근 서구 식습관에 기인하는 여러 가지 만성질환의 증가로 인해 항산화, 항암, 면역증진 및 혈행개선 등의 생리활성을 갖는 약용식물에 대한 연구가 진행되게 되었다. 약용식물은 생체내에서 식균작용을 활성화하고 항체의 생성을 촉진시키 는 등 질병에 대한 방어력을 증가시켜 만성질환을 예방하고 치료하는데 효과적인 것으로 알려져 있다[13,14,29]. 만성질환 은 심장혈관과 장질환, 암, 당뇨병, 류마티스 관절염 그리고 퇴행성 질환 등과 같은 다양한 질환의 위험성을 증가시키기 때문에 항염증효능을 지닌 약용식물이 전통적으로 질환 예방 및 치료에 광범위하게 활용되어 왔다. 염증이란 외상, 감염, 조직 손상, 유해성 자극에 의해 발생되는 신체적 방어 반응으 로써 즉각적인 면역 과정을 유도한다. 즉, 면역세포로부터 nitric oxide (NO), 프로스타글라딘, 인터루킨, 인터페론과 같은 사이토카인을 다량으로 배출시켜 방어기작을 일으킨다[9,27]. 특히 $\mathrm{NO}$ 는 독성물질로써 아테롬성 동맥경화증, 염증, 암 등과 같은 질환의 원인인자와 연관되어 있는데 연구 보고에 의하면 $\mathrm{NO}$ 량이 소량만 증가하더라도 즉각적인 항염증 반응을 면역 세포에 유도시키지만 그 양이 증가한 경우에는 질환을 발생시 킬 수도 있으므로 항염증 효능을 연구하는데 있어서 $\mathrm{NO}$ 량

\footnotetext{
*Corresponding author

Tel : +82-51-999-5459, Fax : +82-51-999-6959

E-mail : yjchoi@silla.ac.kr
}

측정은 필수적이다[17,18]. 하지만, 지금까지 항염증에 있어서 약용식물의 효능에 대한 이러한 객관적 검증은 아직 잘 알려 져 있지 않은 실정이다.

약용식물의 질환 예방 및 치료효능에는 이들의 항산화력도 기인하는 것으로 최근 연구에 보고되어 있다[4,5]. 산화적 스트 레스는 암, 아테롬성 동맥경화증, 당뇨병, 간경변 등과 같은 다양한 질환과 연관되어 있기 때문에 동서양을 막론하고 항산 화력을 지닌 약용식물은 질환치료제 및 건강증진제로 관심이 높아지고 있다[19,25,28]. 특히, 한의학 및 민간요법에서 효능 을 인정받고 있는 약용식물은 플라보노이드와 페놀화합물과 같은 천연 항산화제를 지닌 것으로 알려져 있으므로 다양한 생리활성 분석과 건강음료 개발에 약용식물을 활용하고자 하 는 연구가 이루어지고 있다[4,5]. 지금까지 연구는 일반적으로 한 종류의 약용식물 추출물에 대한 분석이며 여러 종류의 약 용식물을 혼합한 추출물에 대한 분석은 이루어져 있지 않고 있다. 하지만, 한방의 약제 처방에는 여러 종류의 약용식물을 정해져 있는 양에 따라 혼합하여 열탕으로 추출하여 치료 효 과를 추구하고 있으며 대중적으로도 여러 종류의 약용식물 추출물을 혼합한 음료 개발로 건강 기능성을 증대시키고자 하고 있다.

따라서 본 연구에서는 문헌 등을 통해 생리활성효과 등이 있다고 알려진 약재들을 한의학적으로 처방하고 있는 수치에 맞추어[21] 혼합하여 추출시켜서 그 효능에 대해 검증을 하고 자 하였으며 이를 위해 추출물의 면역기능 증진 및 항산화 
효과에 대한 분석을 하고자 하였다.

\section{재료 및 방법}

\section{시료 채취 및 추출}

본 실험에 사용된 실험 재료들은 경상남도 거창 농가와 한 약재 판매상으로부터 구입하였으며, Table 1에 나타낸 수치에 따라 첨가하여 추출시켰다. 이는 민간요법으로 그 효능이 전 해져 내려오고 있는 약재를 한의학적으로 처방하고 있는 수치 에 따라 혼합하여 추출하였다. 추출은 채취한 시료를 동결 건 조시킨 후 분쇄기로 분쇄하고 $30 \mathrm{mesh}$ 이하의 것을 추출용 시료로 사용하였다. 에탄올 추출물은 분쇄된 시료에 $80 \%$ 에탄 올 11 를 첨가하여 실온에서, 열수 추출물은 증류수 11 를 첨가 하여 $90^{\circ} \mathrm{C}$ 에서 각각 24 시간 추출한 후 여과한 다음 rotary evaporator로 농축한 후, 동결 건조하여 얻었다. 그리고 추출 시료들은 $-70^{\circ} \mathrm{C}$ 냉동 보관하며 실험재료로 사용하였다.

\section{$\mathrm{HPLC}$ 분석}

Flavonoid glycoside 분석을 위한 표준용액 $(1 \mathrm{mg} / \mathrm{ml})$ quercetin, kaemferol, myricetin, apigenine, luteolin, rutin을 메 탄 올에 용해시켜 사용하였고, 시료 $(10 \mathrm{mg} / \mathrm{ml})$ 는 메탄올에 용해 한 후 Sea-pak C18 cartridge와 $0.2 \mu \mathrm{m}$ filter로 여과하여 HPLC

Table 1. Mixing amount of TMP1 and TMP2

(unit: g)

\begin{tabular}{lcc}
\hline \multirow{2}{*}{ Scientific name of source } & \multicolumn{2}{c}{ Mixing ratio type } \\
\cline { 2 - 3 } & TMP1 & TMP2 \\
\hline Cassia obtusifolia L. & - & 5.0 \\
Schisandra chinensis & - & 5.0 \\
Lycium chinense & - & 5.0 \\
Mentha arvensis var. piperascens & 2.4 & 5.0 \\
Chrysanthemum indicum L. & - & 7.5 \\
Dioscorea japonica Thunb & 1.0 & 2.5 \\
Zingiberis siccatum Rhizoma & - & 0.5 \\
Polygonatum odoratum var. pluriflorum & 20.0 & 15.0 \\
Glycyrrhiza uralensis & 1.6 & 2.5 \\
Acanthopanax sessiliflorum Seeman & 1.2 & 2.5 \\
Camellia sinensis & 10.0 & 10.0 \\
Taraxacum platycarpum & 2.6 & - \\
Nelumbo nucifera & 2.6 & - \\
Pinus densiflora & 2.0 & - \\
Lilium lancifolium Thunb & 2.0 & - \\
Artemisiae argi Folium & 2.0 & - \\
Plantago asiatica & 2.0 & - \\
Morus alba L. & 2.6 & - \\
Platycodon grandiflorum & 0.6 & - \\
Portulaca oleracea L. & 0.6 & - \\
Perilla frutescens var. acuta & 0.6 & - \\
Inula britannica var. chinensis & 0.6 & - \\
Nelumbo nucifera G. & 1.2 & - \\
Eucommia ulmoides & 2.0 & - \\
\hline & &
\end{tabular}

분석용 시료로 사용하였다. 분석용 column은 Octadecylsilane (ODS) $\mathrm{C} 18(4.6 \times 25 \mathrm{~cm}, 5 \mu \mathrm{m})$ 을 사용하였고, 용매는 $\mathrm{MeOH} / \mathrm{H}_{2} \mathrm{O} /$ Acetic acid $(5 / 93 / 2, \mathrm{v} / \mathrm{v})$ 와 $60 \% \mathrm{MeOH}$ 를 사 용하여 linear gradient해서 55 분간 용출 시킨 후 15 분간은 $60 \% \mathrm{MeOH}$ 로서 용출하였다. Total flow rate은 $1 \mathrm{ml} / \mathrm{min}$ 로 하였고, detector는 UV $370 \mathrm{~nm}$ 에서, column temp. oven은 $30^{\circ} \mathrm{C}$ 로 하여 Shimadzu LC-10AD으로 분석하였다.

\section{전자공여능(Electron donation ability, EDA) 측정}

전자공여능 측정은 Blois의 방법[2]에 따라서 각 시료의 DPPH (1,1-diphenyl- 2-picrylhydrazyl)에 대한 수소공여 효 과로 측정 하였다. 추출시료를 $\mathrm{DMSO}$ 에 녹여 농도별로 희석 하여 시료 $40 \mu 1$ 와 $1.5 \mathrm{mM} \mathrm{DPPH}$ 용액 $160 \mu 1$ 를 섞은 후, $37^{\circ} \mathrm{C}$ 에서 30 분 동안 반응시킨 다음 ELISA reader를 이용하여 520 $\mathrm{nm}$ 에서 흡광도를 측정하였다. 전자공여능(Electron donating ability, $\mathrm{EDA})$ 은 $\mathrm{EDA}(\%)=($ 대조구흡광도-시료첨가구흡광도)/ 대조구흡광도×100으로 계산하였다. 시료를 첨가하지 않은 대 조그룹과 흡광도차를 비교하여 프리라디칼의 제거활성을 백 분율로 나타내었다.

\section{세포배양}

마우스대식세포주인 RAW264.7 세포는 American Type Culture Collection (ATCC, Manassas, VA. USA)에서 구입하 였으며, 세포배양에 사용된 배지인 RPMI 1640 media (Eagle's MEM) 과 fetal bovine serum (FBS), Hank's balanced salt solution (HBSS) 등은 모두 Hyclone (Logan, UT, USA)의 제품을 구입하여 사용하였다. RAW264.7 세포주는 $10 \% \mathrm{FBS}$ 와 100 unit의 penicillin과 streptomycin이 함유된 RPMI 1640 media 를 사용하여 $5 \%$ 의 이산화탄소를 포함한 $37^{\circ} \mathrm{C}$ 의 포화습도 공 기조건 하에서 배양하였다.

Nitric oxide (NO) 생성량 측정 및 cell viability 측정

$\mathrm{NO}$ 의 생성은 비색법으로 세포 상등액에 축적되는 nitrite 양을 측정하였다. 대식세포를 세포 배양판에 $5 \times 10^{5} \mathrm{cells} / \mathrm{ml}$ 의 세포가 되도록 재부유하여 LPS의 자극하에 24시간 배양하고 그 배양 상층액 내의 $\mathrm{NO}$ 를 Griess 시약과 반응시켜 측정하였 다[20]. $100 \mu \mathrm{l}$ 의 세포배양 상층액을 취하여 동량의 Griess 시 약 $[1 \%$ sulfanilamide ( $30 \%$ acetic acid)와 $0.1 \% \mathrm{~N}$-(1-naphthyl) ethylenediamine dihydrochloride $(60 \%$ acetic acid) 혼합액] 을 가하여 상온에서 20 분간 반응시켰다. $\mathrm{NO}$ 의 활성 정도는 ELISA 판독기를 사용하여 $800 \mathrm{\mu g} / \mathrm{ml}$ 농도 범위에서 $540 \mathrm{~nm}$ 흡광도를 측정하였다.

세포독성 실험은 mitochondrial dehydrogenase activity의 index를 나타내는 MTT colorimetric reduction assay 법으로 추출물이 세포생존율에 미치는 영향을 분석하였다[20]. 96-well microtiter plate (Nunc, Vangaard, Neptune, NJ)에 
RAW 264.7 macrophage를 $1 \times 10^{5}$ cells/well의 농도로 분주하 였다. 분주 24시간 후 각 추출물이 함유되어 있는 배지를 100 씨씩 넣어 48시간 동안 배양하였다. Plate에 MTT $2 \mathrm{mg} / \mathrm{ml}$ 3-(4,5-dimethylthiazol-2-yl)-2,5-diphenyl-tetrazolium bromide (MTT, Sigma, USA) 용액을 $20 \mu \mathrm{l}$ 씩 첨가하여 4시간 동안 배양시키고 formazan을 형성시킨 후 조심스럽게 상등액 을 제거하였다. DMSO $150 \mu \mathrm{l}$ 을 첨가하여 formazan을 녹인 후 $570 \mathrm{~nm}$ 에서 흡광도를 측정하였다.

\section{결과 및 고찰}

\section{플라보노이드 함량 분석}

지금까지의 보고에 의하면 항산화능과 플라보노이드의 함 량에는 비례적인 연관성이 있다고 알려져 왔다[23]. 이러한 결 과는 Kang [8]이 감귤껍질에서 플라보노이드를 분리 추출하 여 실시한 산화억제능에서도 동일한 결과를 나타낸 바 있다. 또한 Kim 등[10]이 대두에서 각종 용매를 이용하여 플라보노 이드를 추출하여 실험한 항산화능에서도 동일한 결과를 나타 내었으며 붉나무 순차용매 추출물의 항산화 효과를 비교한 Lee 등[15]의 연구결과에서도 이러한 사실을 입증한 바 있다. 이에 본 연구에서는 두 종류의 약용식물 복합 추출물의 플라 보노이드 함량을 측정하여 그 항산화능을 예측하고자 하였다. 우선, 약용식물 복합 추출물 TMP1과 TMP2의 열수, 에탄올 추출물에 대한 플라보노이드 함량을 HPLC로 정량 분석하였 다(Table 2). 그 결과, quercetin은 TMP1과 TMP2 에탄올 추출 물에서 각각 $230,534 \mu \mathrm{g} / \mathrm{g}$ 의 함량을 보였지만 열수 추출물에 서는 검출되지 않았다. Kaemferol의 함량 또한 TMP1과 TMP2 에탄올 추출물에서 각각 $80,15 \mu \mathrm{g} / \mathrm{g}$ 으로 관찰되었지만, 열수 추출물에서는 검출되지 않았다. Apigenine의 함량 분석에서 는 TMP1 에탄올 추출물 $(1,670 \mu \mathrm{g} / \mathrm{g})$ 이 열수 추출물 $(950 \mu \mathrm{g} / \mathrm{g})$ 보다 1.8 배 높았고, TMP2는 에탄올 추출물 $(1,069 \mu \mathrm{gg} / \mathrm{g})$ 이 열 수 추출물 $(302 \mu \mathrm{g} / \mathrm{g})$ 보다 3.5 배 높은 함량을 나타내었는데, 전
반적으로 TMP1 추출물의 apigenine 함량이 TMP2보다 높았 다. Luteolin의 경우에서도 TMP1 에탄올 추출물 $(1,360 \mu \mathrm{g} / \mathrm{g})$ 이 열수 추출물 $(340 \mu \mathrm{g} / \mathrm{g})$ 보다 4 배나 높았고, TMP2 에탄올 추출물 $(2,536 \mu \mathrm{g} / \mathrm{g})$ 의 경우 열수 추출물 $(673 \mu \mathrm{g} / \mathrm{g})$ 보다 3.8 배 이상 높은 함량이 관찰되었는데, apigenine의 경우와는 다르 게 TMP2 추출물의 luteolin 함량이 TMP1보다 더 높았다. 대표 적인 플라보노이드계 물질인 rutin의 경우에는 TMP1 에탄올 추출물 $(25 \mathrm{mg} / \mathrm{g})$ 이 열수 추출물 $(4.490 \mathrm{mg} / \mathrm{g})$ 보다 5.6 배나 높 았고, TMP2는 에탄올 추출물 $(36.827 \mathrm{mg} / \mathrm{g})$ 에서 열수 추출물 $(9.070 \mathrm{mg} / \mathrm{g})$ 보다 4 배나 훨씬 높은 함량을 보이고 있는데, 역 시 TMP1보다 TMP2에서 더 높은 함량을 나타내었다. 이에반 해 myricetin은 전혀 관찰되지 않았다. 이로써 총 플라보노이 드의 함량은 TMP2 추출물이 높았는데 특히, 에탄올 추출물이 가장 높이 나타났으며 그 다음으로 TMP1 에탄올 추출물이었 다. 이는 Table 3에서 보이는 높은 라디칼 소거능과 일치한다. 지금까지의 약용식물의 플라보노이드에 대한 보고에 의하면 quercetin과 kampferol 함량이 알려져 있는데, 결명자는 54.5 와 $214.8 \mu \mathrm{gg} / \mathrm{g}$, 감초는 24.7 와 $0 \mu \mathrm{g} / \mathrm{g}$, 구기자는 15.8 와 $7.3 \mu \mathrm{g}$ $/ \mathrm{g}$, 생강은 12.0 와 $0 \mathrm{\mu g} / \mathrm{g}$ 으로 알려져 있다[16]. 이들에 의하면 결명자보다 감초의 플라보노이드 함량이 적음에도 불구하고, 총 페놀함량은 $3,510 \mu \mathrm{g} / \mathrm{g}$ 으로 결명자의 총 페놀함량 $672 \mu \mathrm{g}$ $/ \mathrm{g}$ 보다 5 배나 많은 것으로 보고되었다. 또한 $\operatorname{Lim}$ [16]과 Moon [22]의 보고에 의하면 총 페놀함량이 국화에서 2,480 $\mu \mathrm{g} / \mathrm{g}$, 감초는 $4,690 \mu \mathrm{g} / \mathrm{g}$, 녹차 $10,980 \mu \mathrm{g} / \mathrm{g}$, 박하 $1,460 \mu \mathrm{g} / \mathrm{g}$ 으로 상당히 높은 함량을 나타내고 있다. 구기자와 생강의 총 페놀함량은 66 과 $49 \mathrm{\mu g} / \mathrm{g}$ 으로 낮은 함량을 비록 보고 하고 있지만, 본 연구결과와 문헌의 분석에 의하면 TMP2 추출물의 다량의 플라보노이드 함량으로 높은 항산화능을 예측할 수 있다.

$\mathrm{DPPH}$ 에 의한 항산화 활성

인체 내의 free radical은 지질, 단백질등과 반응하여 생

Table 2. The contents of flavonoids of hot water and ethanol extracts from TMP1 and TMP2

$(\mathrm{mg} / \mathrm{g})$

\begin{tabular}{lcccc}
\hline \multirow{2}{*}{ Flavonoids } & \multicolumn{2}{c}{ TMP1 } & \multicolumn{2}{c}{ TMP2 } \\
\cline { 2 - 5 } & WE & EE & WE & EE \\
\hline Quercetin & - & $0.23 \pm 0.003$ & - & $0.534 \pm 0.003$ \\
Kaempferol & - & $0.08 \pm 0.002$ & - & $0.015 \pm 0.002$ \\
Myricetin & - & - & - & - \\
Apigenin & $0.95 \pm 0.005$ & $1.67 \pm 0.004$ & $0.302 \pm 0.005$ & $1.069 \pm 0.004$ \\
Luteolin & $0.34 \pm 0.004$ & $1.36 \pm 0.003$ & $0.673 \pm 0.004$ & $2.536 \pm 0.003$ \\
Rutin & $4.49 \pm 0.007$ & $25.21 \pm 0.005$ & $9.070 \pm 0.007$ & $36.827 \pm 0.005$ \\
Total & $6.59 \pm 0.006$ & $28.23 \pm 0.007$ & $10.046 \pm 0.006$ & $40.981 \pm 0.007$ \\
\hline
\end{tabular}

Flavonoids were analyzed by HPLC.

Each values are mean \pm S.D. of triplicate measurements.

WE: Hot water extracts from TMP1 and TMP2.

EE : Ethanol extracts from TMP1 and TMP2. 
Table 3. DPPH free radical scavenging activities of hot water and ethanol extracts from TMP1 and TMP2

\begin{tabular}{cccccc}
\hline \multirow{2}{*}{$\begin{array}{c}\text { Concentration } \\
(\mathrm{mg} / \mathrm{ml})\end{array}$} & Vit C & WE & EE & WE & TMP2 \\
\cline { 2 - 6 } & & ND & $13.7 \pm 1.5$ & ND & $36.7 \pm 1.7$ \\
0.05 & $69.7 \pm 2.9$ & ND & $26.0 \pm 2.4$ & ND & $42.8 \pm 1.1$ \\
0.5 & $96.5 \pm 2.4$ & $51.0 \pm 0.8$ & $91.2 \pm 1.1$ & $52.8 \pm 0.9$ & $92.2 \pm 1.3$ \\
1.0 & $>99.0$ & $81.0 \pm 0.8$ & $94.0 \pm 1.1$ & $82.3 \pm 1.2$ & $96.2 \pm 0.9$ \\
5.0 & $>99.0$ & $89.2 \pm 3.6$ & $>99$ & $90.5 \pm 2.1$ & $>99$ \\
\hline
\end{tabular}

Each values are mean \pm S.D. of triplicate measurements.

ND: not detected.

WE: Hot water extracts from TMP1 and TMP2.

EE : Ethanol extracts from TMP1 and TMP2.

체의 노화를 촉진할 수 있는 물질로, 이러한 free radical을 제거할 수 있는 천연물질에 대한 연구가 활발히 진행되고 있다. 특히 DPPH (1,1-diphenyl-2-picrylhydrazyl) radical 소거법은 항산화물질의 전자공여능을 이용한 항산화 측정 법으로써 주로 pheonlic 구조와 aromatic amine 화합물에 서 많이 사용되는 방법이다. 이에 본 연구에서 TMP1 열수, 에탄올과 TMP2 열수, 에탄올 추출물의 항산화 효과를 $\mathrm{DPPH}$ radical 제거 정도를 측정하여 나타내었는데 그 결 과 $1 \mathrm{mg} / \mathrm{ml}$ 농도에서 각각 $81.0,94.0,82.3,96.2 \%$ 로 나타
났다(Table 3). 즉, TMP2 에탄올 추출물이 가장 높은 항산 화활성을 나타냈다. 이는 일반적으로 이용되는 positive control인 비타민 C $0.1 \mathrm{mg} / \mathrm{ml}$ 의 전자소거능 $96.5 \%$ 와 비 슷한 수준으로 보이고 있어 그 이용가치가 높음을 시사하 고 있다[20]. 지금까지 약용식물 추출물의 전자소거능에 대 한 보고에 의하면 감초, 녹차, 박하, 국화, 오미자, 구기자 추출물에서 $39.3,94.1,26.3,51.2,49.4,29.8 \%$ 로 나타났는데, 이는 본 연구의 시료인 약용식물 복합 추출물 $\mathrm{TMP} 2$ 의 높 은 항산화능을 뒷받침 하고 있다[7,24]. 이에 반하여 TMP1
A

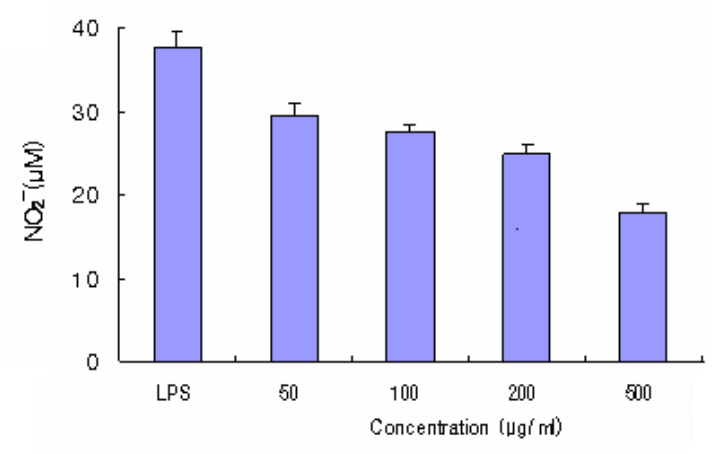

C

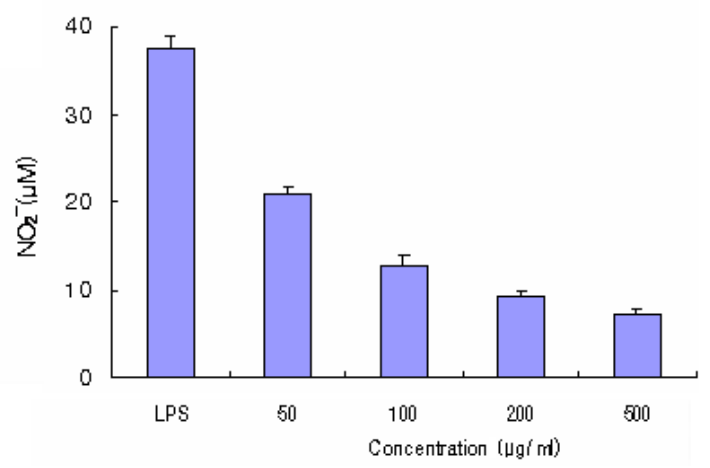

B

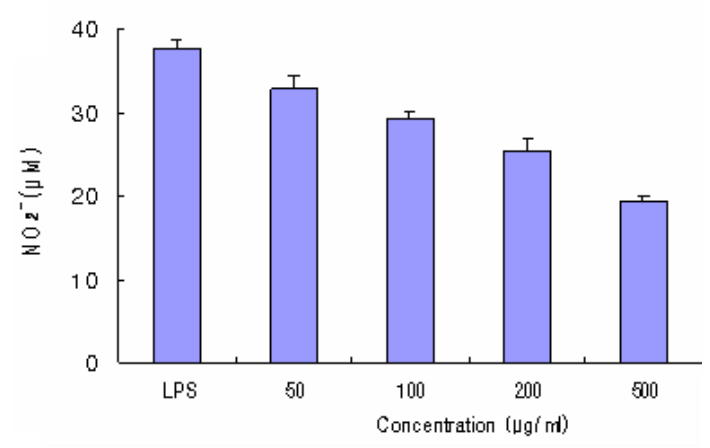

D

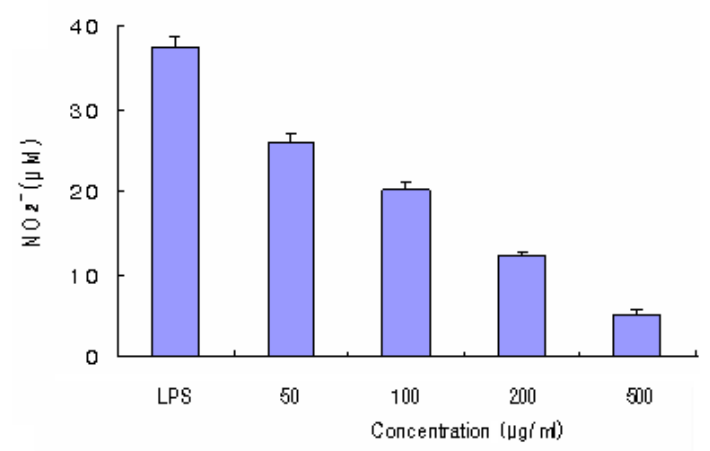

Fig. 1. Inhibitory effects of hot water $(\mathrm{A}, \mathrm{B})$ and ethanol $(\mathrm{C}, \mathrm{D})$ extracts from traditional medicinal plants (TMP) 1 (A, C) and 2 (B, D) on NO production in RAW 264.7 cells stimulated by LPS $(10 \mu \mathrm{g} / \mathrm{ml})$. Values are the mean \pm S.D. of triplicate experiments. 
은 TMP2보다 훨씬 다양한 약재를 추가하여 추출하였지만, $\mathrm{TMP} 2$ 와 유사한 항산화력을 나타내고 있으므로 그 생리활 성의 정도가 약용식물의 가지 수와는 무관함을 확인 할 수 있었다.

\section{항염증 효능 및 cell viability}

대장균 lipopolysaccharide (LPS)는 염증을 유발하는 물질 로써 면역세포에 $\mathrm{NO}$ 합성을 유도시킨다. 따라서, TMP1과 $\mathrm{TMP} 2$ 의 항염증 효능을 분석하기 위해 대식세포에 LPS를 처 리하여 NO를 유도시킨 다음 TMP1과 TMP2 열수, 에탄올 추 출물을 대식세포에 처리하여 NO 활성에 미치는 영향을 조사 하였다(Fig. 1). 그 결과, LPS에 의하여 유도된 대식세포의 NO 합성은 각각의 시료를 농도별로 첨가하였을 때 점차 감소하였 다. 즉, $500 \mu \mathrm{g} / \mathrm{ml}$ 의 TMP1 열수, 에탄올 추출물과 TMP2 열수, 에탄올 추출물을 처리함으로써 LPS에 의해 생성된 $\mathrm{NO}$ 량을 각각 $55,82,48,87 \%$ 감소시켰다(Fig. 1A-D). 과량의 $\mathrm{NO}$ 는 분비조직과 세포의 기능에 악영향을 미치며, 세포성 면역계의 주된 역할의 하나로 세포 독성이나 성장 억제 작용을 하는 것으로 보고 되어 있는데, 본 연구 결과는 $\mathrm{TMP} 1$ 과 $\mathrm{TMP} 2$ 로
부터의 성분들이 $\mathrm{NO}$ 생성을 억제 함으로써 항염증 효능을 나타내고 있음을 보여준다[6]. 지금까지 연구된 LPS에 의한 약용식물의 $\mathrm{NO}$ 합성 저해효과는 Seo 등[26]이 $50 \%$ 이상의 $\mathrm{NO}$ 생성 저해능을 $100 \mu \mathrm{g} / \mathrm{ml}$ 의 봉선화, 금불초, 산옥잠화, 모시풀등과 같은 약초의 메틸 추출물에서 보고하였다. 이는 본 연구에서 이용된 TMP2 에탄올 추출물과 유사한 NO 합성 저해율을 나타내고 있다(Fig. 1D). Ahn 등[1]은 본 연구결과와 유사한 도라지의 NO 합성 저해율을 보고하였는데, 우수한 $\mathrm{NO}$ 합성 저해율로 차세대 염증질환 치료제와 예방약으로 활 용할 수 있을 것으로 판단하고 있다. 이는 역시 본 연구에서 분석된 TMP2의 활용도를 대변하고 있다. 즉, TMP2 에탄올 추출물(Fig. 1D)이 열수 추출물(Fig. 1B)보다 항염증 효능이 높은 것으로 보여지고 있으며 TMP1 (Fig. 1A, C)보다 약용식 물의 가지 수가 적음에도 불구하고 유사한 항염증 효능을 보 여주고 있으므로 추출용매에 따라 그 생리활성의 정도는 달라 질 수 있지만 약용식물의 가지 수와는 무관함을 확인 할 수 있었다.

추출물에 대한 세포독성은 MTT 분석을 통해서 측정하였는 데, 그 결과 시료를 처리한 대식세포의 세포생존율이 $90 \%$ 정도
A

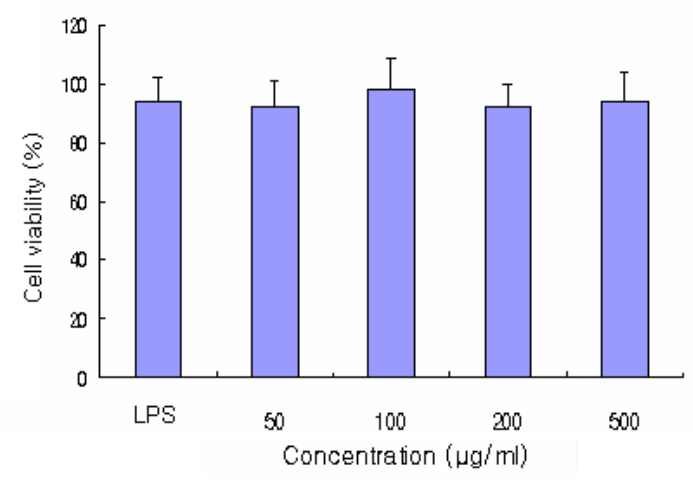

C

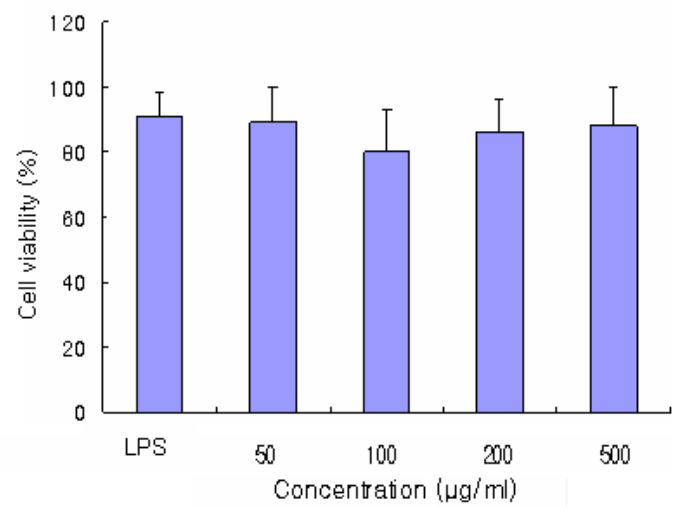

B

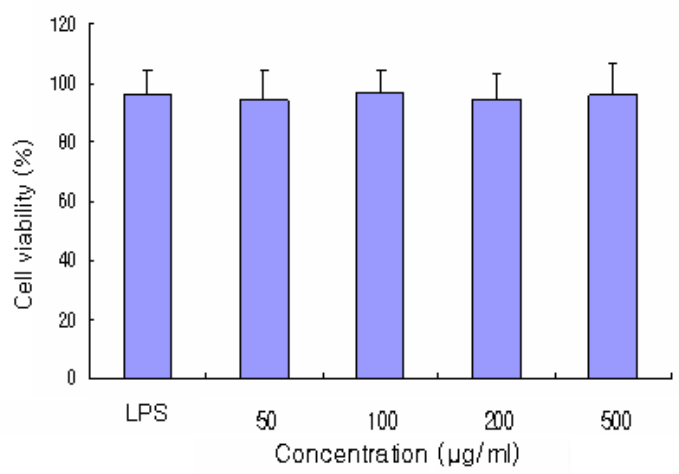

D

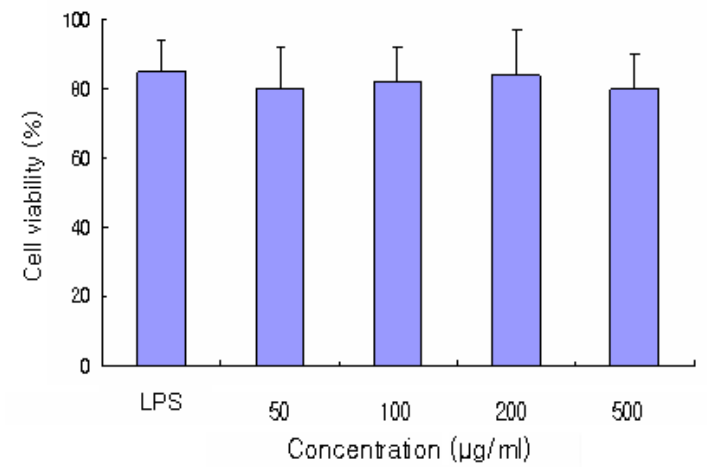

Fig. 2. Effects of hot water (A, B) and ethanol (C, D) extracts from traditional medicinal plants (TMP) 1 (A, C) and 2 (B, D) on cell viability in bacterial LPS-stimulated RAW264.7 macrophages. RAW264.7 cells were cultured for $24 \mathrm{hr}$ with various concentration of extracts in the presence of LPS $(10 \mu \mathrm{g} / \mathrm{ml})$. NO release was measured using the method of Griess (nitrite). Cytotoxicity was determined by MTT assay. Results are presentated as means \pm S.D. of three independent experiments. 
를 나타내는 바 본 연구에서 사용된 시료에 대한 세포독성은 없는 것을 알 수 있었다(Fig. 2). 따라서, 실험결과에 나타난 $\mathrm{NO}$ 의 생성량의 변화가 추출물의 세포독성에 의한 영향과는 무관한 것으로 판단 할 수 있었다.

\section{대식세포에서의 Nitric oxide 생성능 측정}

과량의 $\mathrm{NO}$ 는 염증을 유발하는 물질로써 보고되어 있지만 일정량의 $\mathrm{NO}$ 는 대부분의 포유류 동물세포내에서 생성되는 것으로 신경계에서는 화학적 신호 전달 물질로서, 혈관계에서 는 혈압 조절과 혈소판의 응집 및 호중성구의 집합 작용을, 골격근에서는 대사와 근 수축 조절 등 생리학적으로 중요한 역할을 한다[3,30]. 뿐만 아니라 면역 세포에서 NOS (nitric oxide syntase)에 의해 생성되는 $\mathrm{NO}$ 는 외부의 자극에 의해 유전 자 수준에서 발현되고 주로 침입한 미생물이나 종양 세포를 파괴하는 자기 방어 물질로서도 작용하는 것으로 알려져 있다 $[11,26]$. 최근에는 NO가 세포 활성화 물질 및 reactive oxygen intermediates (ROI)에 의해 유발된 세포 독성을 최소화 시키 는 역할이 밝혀짐으로 인해 이 분야에 대해서 활발히 연구되 고 있다[12,31]. 이에 본 연구에서는 약용식물 TMP1과 TMP2 추출물을 대식세포에 투여하였을 때 $\mathrm{NO}$ 의 생성능을 확인하 였는데 그 결과를 Fig. 3 에 나타내었다. 결과에서도 확인할 수
있는 것처럼 대식세포가 생성하는 NO량 보다 TMP1 열수, 에탄올 추출물과 TMP2 열수, 에탄올 추출물 $500 \mu \mathrm{g} / \mathrm{ml}$ 을 첨 가한 결과에서 7.18, 4.6, 2.6, $3.9 \mu \mathrm{M}$ 의 $\mathrm{NO}$ 량이 관찰되었는데, 대조군보다 각각 3.6, 2.3, 1.8, 2.9배 증가하였다(Fig. 3A-D). 과량의 $\mathrm{NO}$ 생성은 세포에 독성을 유발 할 수 있으나 소량 증가 는 자기 방어 기능을 하게 하기 때문에 TMP1 (Fig. 3A, C)과 $\mathrm{TMP2}$ (Fig. 3B, D) 약용식물 추출물이 면역활성과 관련하여 활용 가능성이 있음을 확인 할 수 있으며 TMP1 열수 추출물 (Fig. $3 \mathrm{~A}$ )이 보다 높은 면역활성의 증진이 있음을 관찰 할 수 있었다. 지금까지의 연구는 주로 침입한 미생물이나 종양 세 포가 분비하는 독성물질로 유발되는 NO 생성을 저해함으로 써 항염증 효능에 대한 연구를 해 왔으며 방어 물질로 또는 독성을 최소화 시킬 수 있는 물질로써의 $\mathrm{NO}$ 생성 활성에 대한 연구는 거의 없는 것으로 판단된다. 따라서, 본 연구는 약용식 물에 의한 $\mathrm{NO}$ 생성량 증대로 인한 항염증 효능에 대한 분석으 로써 새로운 학술적 의미를 가진다고 판단된다. 하지만, $\mathrm{NO}$ 량 에 따른 생리활성에 미치는 영향에 대한 보고 및 연구가 부족 하므로 이에 대한 연구가 더욱 필요하다. 이 이외에도 $\mathrm{NO}$ 는 매우 약한 산화성을 가진 라디칼로서 비타민 $\mathrm{E}$ 와 비슷하게 세포의 지질과산화물을 막는 항산화 기능도 수행한다는 보고 도 있으므로, 약용식물에 의한 $\mathrm{NO}$ 생성량 증대에 대해 더욱
A

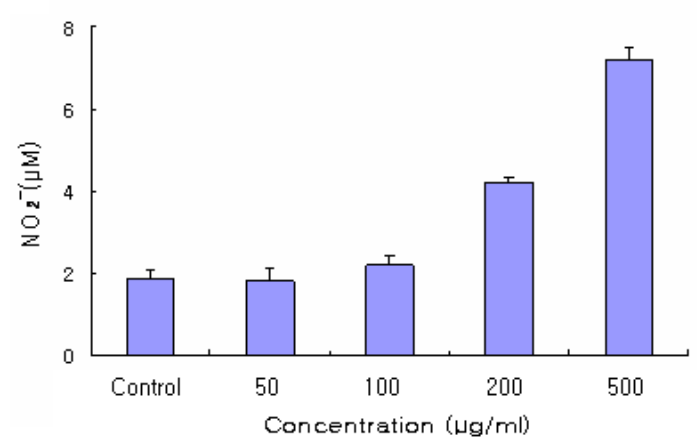

C

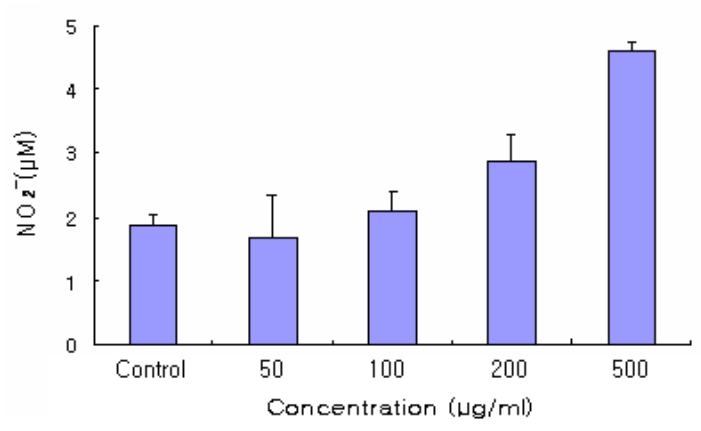

B

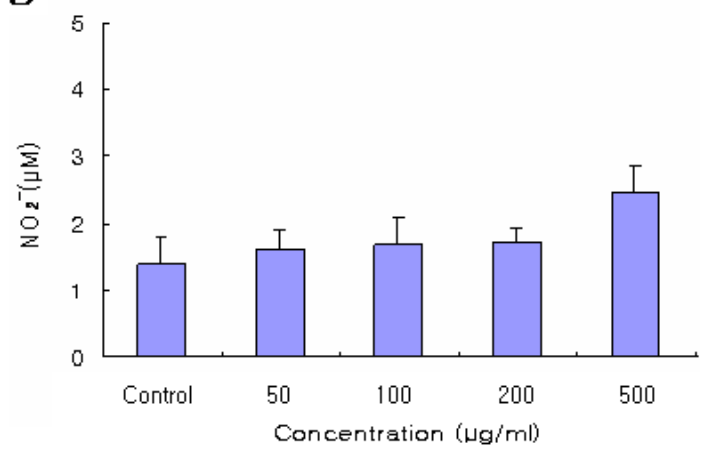

D

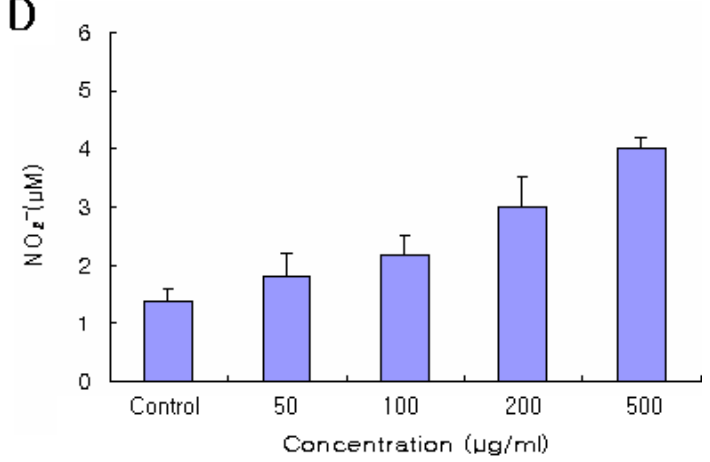

Fig. 3. Induction of NO production by hot water $(\mathrm{A}, \mathrm{B})$ and ethanol $(\mathrm{C}, \mathrm{D})$ extracts from traditional medicinal plants (TMP) 1 (A, C) and 2 (B, D) depending on concentration. NO production was determined in macrophage RAW 264.7 cells. Values are the mean \pm S.D. of triplicate experiments. 
비중 있는 연구가 이루어져야 할 것으로 판단된다.

\section{References}

1. Ahn, K. S., E. J. Noh, H. L. Zhao, S. H. Jung, S. S. Kang, and Y. S. Kim. 2005. Inhibition of inducible nitric oxide synthase and cyclooxygenase II by Platycodan grandiflorum saponins via suppression of nuclear factor-kB activation in RAW 264.7 cells. Life Sci. 76, 2315-2328.

2. Blois, M. S. 1958. Antioxidant determination by the use of a stable free radical. Nature 26, 1199-1200.

3. Hierholzer, C., B. Harbrecht, J. M. Menezes, J. Kane, J. MacMicking, C. F. Nathan, A. B. Peitzman, T. R. Billiar, and D. J. Tweardy. 1998. Essential role of induced nitric oxide in the initiation of the inflammatory response after hemorrhagic shock. J. Exp. Med 187, 917-928.

4. Hyun, S. H., S. K. Jung, M. K. Jwa, C. K. Song, J. H. Kim, and S. B. Lim. 2007. Screen of antioxidants and cosmeceuticals from natural plant resources in Jeju island. Korean J. Food Sci. Technol. 39, 200-208.

5. Jeon, H. S, Y. S. Lee, and N. W. Kim. 2009. The antioxidative activities of Torreya nucifera seed extracts. J. Korean Soc. Food Sci. Nutr. 38, 1-8.

6. Jeon, J. R., J. Y. Kim, K. M. Lee, and D. H. Cho. 2005. Anti-obese effects of mixture contained pine needle, black tea, and green tea extracts. J. Korean Soc. Appl. Biol. Chem 48, 375-381.

7. Jeon, T. W., J. H. Park, M. G. Shin, K. H. Kim, and M. W. Byun. 2003. Effects of gamma-irradiation on biological activities and color changes of extracts of Schizandrae fructus. J. Korean Soc. Food Sci. Nutr. 32, 137-142.

8. Kang, J. H. 1993. Studies on the antioxidative effect and the inhibitory effect on the DNA damage of bioflavonoid extracted from Citrus sinensis. Kosin J. Health Sci. 3, 74-81.

9. Kang, J. M., I. H. Cha, Y. K. Lee, and H. S. Ryu. 1997. Identification of volatile essential oil and flavor characterization and antibacteroal effect of fractions from Houttuynia cordata thunb. J. Korean Soc. Food Sci. Nutr. 26, 209-213.

10. Kim, J. Y., Y. S. Maeng, and G. Y. Lee. 1995. Antioxidative effects of soybean extracts by using various solvents. Korean J. Food Sci. Technol. 27, 635-639.

11. Kim, Y. S. and D. H. Shin. 2004. Volatile components and antibacterial effects of pine needle (Pinus densflora S. et Z.) extracts. Food Microbiol. 22, 37-45.

12. Krncke, K. D., K. Fehsel, and V. Kolb-Bachofen. 1997. Nitric oxide: cytotoxicity versus cytoprotection-How, why, when, and where? Nitric Oxide 1, 107-120.

13. Lee, M. K., G. P. Choi, L. H. Ryu, G. Y. Lee, C. Y. Yu, and H. Y. Lee. 2004. Enhanced immune activity and cytotoxicity of Artemisia capillaris thunb. extracts against human cell lines. Korean J. Medicinal Crop Sci. 12, 36-42.

14. Lee, S. E., H. J. Hwang, J. S. Ha, H. S. Jeong, and J. H. Kim. 2003. Screening of medical plant extracts for antioxidant activity. Life Sci. 73, 167-179.

15. Lee, Y. J., D. H. Shin, Y. S. Chang, and W. S. Kang. 1993.
Antioxidative effect of Rhus javanica Linne extract by various solvents. Korean J. Food Sci. Technol. 25, 677-682.

16. Lim, J. D., C. Y. Yu, M. J. Kim, S. J. Yun, S. J. Lee, N. Y. Kim, and I. M. Chung. 2004. Comparision of SOD activity and phenolic compound contents in various Korean medicinal plants. Korean J. Medicinal Crop Sci. 12, 191-202.

17. Luss, H., N. C. Nussler, H. G. Beger, and A. K. Nussler. 1996. Expression and detection of inducible nitric oxide synthase in experimental models of inflammation. Methods 10, 51-60.

18. Ma, S. J. 2000. Inhibitory effect of onion seasoning on angiotensin converting enzyme. J. Korean Soc. Food Sci. Nutr. 29, 395-400.

19. Makris, D. P. and J. T. Rossiter. 2001. Comparison of quercetin and non-orthohydroxy flavonoid as antioxidants by competing in vitro oxidation reactions. J. Agric. Food Chem 49, 3370-3377.

20. Marletta, M. A. 1993. Nitric oxide synthase structure and mechanism. J. Biol. Chem 268, 12231-12234.

21. Ministry of Health. 2003. Hanyakcheobangjosasurokjip.

22. Moon, J. S., S. J. Kim, Y. M. Park, I. S. Hwang, E. H. Kim, J. W. Park, I. B. Park, S. W. Kim, S. G. Kang, Y. K. Park, and S. T. Jung. 2004. Activities of antioxidation and alcohol dehydrogenase inhibition of methanol extracts from some medicinal herbs. Korean J. Food Preserv. 11, 201-206.

23. Parejo, I., F. Viladomat, J. Bastida, A. Rosas-Romero, N. Flerlage, J. Burillo, and C. Conida. 2002. Comparision between the radical scavenging activity and antioxidant activity of six distilled and nondistilled Mediterranean herbs and aromatic plants. J. Agric. Food Chem 50, 6882-6890.

24. Park, S. J., W. J. Park, B. C. Lee, S. D. Kim, and M. H. Kang. 2006. Antioxidative activity of different species Lycium chinensis Miller extracts by harvest time. J. Korean Soc. Food Sci. Nutr. 35, 1146-1150.

25. Park, Y. E, H. M. Cho, H. J. Lee, Y. S. Hwang, S. S. N. Choi, S. J. Lee, E. S. Park, J. D. Lim, and M. G. Choung. 2007. Antioxidant and inhibition on angiotensin converting enzyme activity of colored potato extracts. Korean J. Crop Sci. $52,447-452$.

26. Seo, J. S., T. H. Lee, S. M. Lee, S. E. Lee, N. S. Seong, and J. Y. Kim. 2009. Inhibitory effects of methanolic extracts of medicinal plants on nitric oxide production in activated macrophage RAW 264.7 cells. Korean J. Medicinal Crop Sci. $17,173-178$.

27. Shim, S. M., S. W. Choi, and S. J. Bae. 2001. Effects of Punica granatum $\mathrm{L}$. fractions on quinone reductase induction and growth inhibition on several cancer cells. J. Korean Soc. Food Sci. Nutr. 30, 80-85.

28. Song, H. S., H. J. Moon, B. E. Park, B. S. Choi, D. J. Lee, J. Y. Lee, C. J. Kim, and S. S. Sim. 2007. Anti-oxidant activity and whitening activity of bamboo extracts. Yakhak Hoeji 51, 500-507.

29. Sun, T. and S. A. Tanumihardjo. 2007. An integrated approach to evaluate food antioxidant capacity. J. Food Sci. 72, 159-165.

30. van der Veen R. C. 2001. Nitric oxide and T cell immunity. 
Int. Immunophamacol. 1, 1491-1500.

31. Wink, D. A., J. A. Cook, R. Pacelli, W. DeGraff, J. Gamson, J. Liebman, M. C. Krishna, and J. B. Mitchell. 1996. The effect of various nitric oxide-donor agents on hydrogen per- oxide-mediated toxicity: a direct correlation between nitric oxide formation and protection. Arch Biochem Biophys. 331, 241-248.

\section{초록 : 약용식물 복합 추출물 TMP1과 TMP2의 항산화능과 염증 억제 효과}

조은경 · 최영주*

(신라대학교 의생명과학대학 식품영양학과)

본 연구에서는 약용식물 TMP1과 TMP2의 기능성에 관한 분석을 위하여 열수, 에탄올 추출물로 여러 가지 생 리활성과 면역활성에 대하여 분석하였다. 우선, TMP1과 TMP2의 항산화능을 플라보노이드 함량 측정으로 예측 하고자 TMP1과 TMP2의 열수, 에탄올 추출물의 총 플라보이드 함량을 조사하였다. 그 결과, TMP2 에탄올 추출 물이 $40.981 \mathrm{mg} / \mathrm{g}$ 으로 가장 높았으며, 이는 높은 항산화능과 연관성이 있는 것으로 나타났는데, DPPH법을 통해 측정한 $\mathrm{TMP} 2$ 의 항산화력은 $1 \mathrm{mg} / \mathrm{ml}$ 농도에서 에탄올 추출물이 $96 \%$ 의 radical 소거능을 나타내었다. 0.1 $\mathrm{mg} / \mathrm{ml}$ 의 비타민 C와 비교 했을 때 유사한 항산화력이 측정되었는데, 이것은 높은 항산화능을 나타내고 있는 것으로 TMP2의 높은 이용가치를 의미한다. TMP2와 면역활성과의 연관성은 LPS에 의해 유도되는 NO 합성 저 해률과 TMP2에 의한 대식세포의 NO 합성 증진율 분석으로 조사되었다. 그 결과 LPS에 의해 유도된 NO 합성 저해율은 $0.5 \mathrm{mg} / \mathrm{ml}$ 농도에서 $\mathrm{TMP} 2$ 열수, 에탄올 추출물이 각각 $47 \%, 86 \%$ 로 나타나 약용식물 TMP2의 높은 면역효과를 증명하고 있다. 또한 TMP2 에탄올 추출물은 3 배의 높은 NO 합성률을 보였다. 지금까지의 연구에 의하면 NO 합성율 증대로 인한 약용식물 추출물의 항염증 효능에 대한 보고가 미비하므로 본 연구는 학술적 의미가 크다고 판단된다. 이상의 결과는 약용식물 TMP2의 우수한 생리활성을 증명하고 있고, 항산화력, 면역활 성 효과가 높은 것으로 나타나 기능성 음료의 소재로서 그 활용도가 높을 것으로 판단된다. 